\title{
Narrating a Significant Past: Historical Writing and Engaged History
}

\author{
Mary Fulbrook
}

The historian can only be jealous of the fiction writer's capacity to evoke characters, places, experiences and emotions, to get inside people's minds and represent internal subjective states in ways that are closed to the historian. The writer of fiction can evoke empathic identification with different characters, and make imagined worlds seem utterly real, once the reader is 'lost' in the imagined world of the book. In contrast to the historian, the writer of fiction is by definition expected to invent characters, scenes, mentalities, dialogues, interior monologues, plots, without reference to any notion of 'what actually happened' or 'what we can know from the evidence to have actually or probably been the case'; the writer of fiction has freedom to roam in quite improbable ways, to fantasise, to indulge in writing satire or magical realism, to explore the impossible, to write about the future, to play with time and place in ways utterly alien to the craft of the historian.

All this is obvious. On the other hand, the ways in which historians write, and the degrees of similarity with fiction writers - in so far as historians are also engaged in a form of creative writing - is less frequently discussed. Literary scholars, with only rare exceptions, tend to stick to critiques and analyses of works of creative fiction, including perhaps memoirs and autobiographies, but only infrequently analysing, at one end of the spectrum, oral history testimonies (as in the work of Lawrence Langer), and, at another, the writings of historians (as in the work of Hayden White). Philosophers of history have however been influenced massively by some literary theorists, in turning their own attention to the significance of such analysis for the nature of history (Langer 1991, White 1987; cp. also Fulbrook 2002). In particular postmodernist theorists, building on Hayden White's seminal arguments, have sought to suggest that history is itself a form of fiction, in that historical narratives are 'created' from rather than 'found' in the past. I do not agree with the more extreme versions of postmodernism, but believe it is fruitful to explore some of the ways in which notions of how to write history may be extended and challenged. I shall focus here on examples relating to the Holocaust, which inevitably arouses strong emotional responses; and particularly on questions of subjectivities and the implications for the significance and readability of works of history.

Insofar as practising historians think about the question of objectivity at all, they tend to adopt the position of Max Weber. 'Values' may, on this view, determine selection of the object of inquiry; and they may affect what we decide to do as a result of our investigation; but they should play no role in the actual process of investigation itself, nor in the reporting of the outcomes. Even where 
the subjectivity of the historian is explicitly acknowledged as an issue, many practising historians see it as sufficient to announce their own situated identity at the outset, perhaps in a Preface, and then ignore it for the bulk of the investigation. Most historians pursue their craft without spending much time pondering the implications of their own position for the ways in which they write history.

The study of an emotive recent past prompts us to reconsider these questions. Histories of a recent past - a past with which we feel close connections, even if we have not lived through it ourselves - raise questions about the ways in which a historian's subjectivity is itself part of the research, inflecting both interpretation and outcome. There are several levels at which subjectivity is an issue. One relates to the object of analysis: what difference does it make to focus on subjective perceptions and emotions in the past, rather than remaining at the level of events and behaviour, of structures and patterns? Secondly, there are methodological questions when using 'ego-documents' to try to understand past subjectivities. There are inevitable ambiguities when interpreting how, in different communicative contexts, a person will reveal their own feelings, their sense of self, their perceptions of others, and their being in time, with a fractured past and an uncertain future. How can we be sure about our own later interpretations, particularly since historians are not psychologists? Oral historians have increasingly come to address these questions, but there remains a great deal more to be explored when dealing with written sources. This is an area where there has been an enormous collection of personal accounts, as in trial testimonies, therapeutic encounters, or memorialisation activities. ${ }^{1}$ Thirdly, there are ethical considerations. What duties, if any, do historians owe not only to the subject, but also to the interpretations proffered by relatives and friends about a person they knew far more intimately than the historian does? Finally, there are questions related to the practice of writing. How do we use, integrate, or incorporate the subjective voices of the past into our professional writing? Particularly when we are, for one or another reason, ourselves deeply entangled in this past, how do we incorporate the conflicting views of others into our accounts?

I will not be able to deal with all these issues here, but would like to raise a few key aspects for discussion. Some of the examples are drawn from my previous work on generations (Fulbrook 2011), and some from current research on legacies of Nazi persecution. ${ }^{2}$ The most problematic issues I depict here, however, derive from my own experiences in writing a particularly personal book, $A$ Small Town near Auschwitz: Ordinary Nazis and the Holocaust (Fulbrook 2012), which lies behind the urgency of some of my wider reflections here.

1 Lynn Abrams briefly discusses the issues raised by oral history interviews with survivors of traumatic events (Abrams 2010: $93 \mathrm{ff}$.).

2 Current work on a book provisionally entitled Living with a Nazi Past. 


\section{The subjectivity of others: 'History from within'}

One area where writers of fiction have a huge advantage over historians is that of the representation of subjectivities. Fiction can (seem to) give us a sense of access to the interiors of others' minds, in a way that historians never can. Historians are tied by the evidence, which is always limited, fragmentary, open to a variety of possible interpretations. Historians often even seem to ignore historical subjectivities almost entirely. And when they do focus on subjective experiences, questions may arise about how best to integrate these into wider accounts dealing with events, structures, processes of which individuals may have been entirely unaware.

For a considerable period of time after the Second World War, German historians tended to write in a style which generally eschewed questions of individual subjectivity as far as 'ordinary people' were concerned. The focus was predominantly on structures of power, significant historical events, the individual motives and decisions of key politicians or other historical personalities, and their consequences, but not on the subjective perceptions, experiences, emotions and personal relationships of 'ordinary people'. From the 1950s through at least to the 1970s, analysis of 'ego-documents' was not part of the dominant methodological arsenal. Political histories, event histories, histories of parties and prominent individuals predominated, while 'mentalities' were viewed as an aspect of intellectual history or history of ideas; the complex intimacies of social relations were regarded as more or less irrelevant to the grand sweep of History with a capital $\mathrm{H}$. Even the so-called Bielefeld School of social historians focussed on structural aspects of societal history, with ordinary people often curiously missing as agents in their own history. When challenged in the later 1970s and 1980s by a combination of Alltagsgeschichte and the 'cultural turn', a standard response by historians such as Hans-Ulrich Wehler, doyen of the Bielefeld School, was that such an approach would merely trivialise history, idealise the 'little man', and fail to explain the wider picture of power relations and major historical developments. ${ }^{3}$

This approach to subjective experiences in history curiously paralleled the use of witness testimony in the courtrooms at this time. Ordinary people's experiences of the past were treated as evidence in relation to alleged criminal acts; their memories were interesting only insofar as they were detailed and reliable in questions of guilt or otherwise, and not in their own right. 'Testimony' was about the object of inquiry - the acts of others - and not about the subjectivity or life story of the individual who stood as witness to the past. This approach only began to change in the later 1970s. ${ }^{4}$

Histories of the everyday lives of subordinate groups have, in the meantime, flourished, and proved their value. 'History from below', histories of popular

3 See for example Kocka (1986a, 1986b: 132-76), Borscheid (1986), and Wehler (1988).

4 There is not space to develop this further here; I discuss it more extensively in a forthcoming book on Living with a Nazi Past. 
opinion, histories of political dissent, from the Munich Centre for Contemporary History 'Bavaria project' of the later 1970s onwards, have shifted our understanding of the ways in which people participated in both sustaining and challenging Hitler's charismatic authority, and more than demonstrated that a focus on structures of power and repression, or official propaganda and ideology, are insufficient to explain the multiple attractions, pressures and constraints of life in the Third Reich. Even so, such approaches have, in the work of most historians, tended to remain at a certain level of generality and indeed anonymity. The documents deployed provide evidence of broader trends in 'popular opinion': Sopade and SD reports provide snapshot illustrations of general mood and response to particular developments, but not insights into the private lives and emotion-laden relationships of individuals over a longer period of time. ${ }^{5}$

Closer to what we are talking about here are approaches to historical lives through the analysis of ego-documents with developments in oral history since the 1980s. While initially this was treated by some historians as a way of finding out more about subjugated aspects of the past than could be discovered through official records and archival sediments, it has increasingly been used to explore the subjectivities and discourses of a later date. In this respect, it can provide a key element - though far from the only one - in the methodological toolbox of 'history from within'.

What then is the potential of a history of subjectivities? There are several aspects worthy of discussion.

First, such an approach can help us to revise received narratives, in that it foregrounds agency and individual difference in history. In my work on generations through the German dictatorships, I became acutely aware of the ways in which individuals had degrees of choice, and might respond very differently to apparently similar challenges. Sebastian Haffner, for example, of the same 'war youth generation' as many convinced Nazis, chose not to bend his principles in order to foster his legal career under the Nazi state, and chose instead to emigrate to the UK and turn to journalism (Haffner 2002). Yet there were certain features that did indeed stamp their mark on what was a politically divided generation. Both on the extreme right and on the extreme left, there was a willingness to contemplate physical violence as a supposedly legitimate means to achieve particular goals; there was also a willingness to absorb the individual self into a wider collective, in service of a broader cause. It is often overlooked, when analysing the role of the 'generation of the unbound' in the Third Reich, that the founding fathers of the GDR were drawn from precisely the same 'war youth generation' as those who staffed the Reichssicherheitshauptamt (RSHA) of the Third Reich; and that the

5 Sopade was the name given to the German Social Democratic Party in exile during the Third Reich. Social Democrats who remained in Germany wrote frequent detailed reports on conditions, mood and opinions under Nazi rule. The SD was the Security Service (Sicherheitsdienst) of the SS. 
leading lights and core functionaries of the GDR - the '1929ers' - were drawn from the same 'Hitler Youth generation' as the cultural and public elites of the FRG. History from within can help us understand the combination of cultural receptivity and structural opportunities and constraints that explain the different life patterns of common cohorts under different circumstances.

Analysis of subjectivities can also help us to understand the ways in which structural violence was socially enacted. Innumerable life stories reveal the extraordinary replication of similar experiences, as in the widely prevalent tales of friendships being broken off after Hitler came to power, when 'Aryans' felt that it was problematic to remain on intimate terms with Jewish friends, colleagues and neighbours. Analysis of behaviour and outward conformity to new scripts as well as subjective experiences of changing personal relationships can also help us to see the deep and lasting consequences - often highly painful, at a personal level - for the victims. Precisely the breaking off of previously intimate relations was a way of progressively isolating those who suffered what Marian Kaplan has called a 'social death' long before they were actually deported and murdered (Kaplan 1998). The old debates, juxtaposing or counter-posing repression and ideology, force and persuasion, terror and enthusiasm, need to be revised and rendered more complex by the insights derived from an understanding of subjectivities, of the distinctions between inner views and behavioural conformity, as well as the implications for others.

This leads to the second way in which such an approach is crucial. For it helps us to understand the ways in which people are themselves shaped by living within certain political structures, pressures and constraints - and the ways in which they live on, with both continuities and changes, beyond major historical and social caesurae. How did former Nazis 'become' East Germans or West Germans? Analysis of ego-documents can provide some startling examples of apparently perfect transformations that are so complete that even the subject appears to believe their own story. Ursula B., for example, was a committed Nazi whose husband went missing at Stalingrad. Her diary of the time reveals unthinking alignment with Nazi racial thinking and practice. Yet her private memoirs, penned several decades later in the GDR for members of her family, manage to excise all of this entirely from her subsequent record of her life, and apparently from her own memory. The continuity which allowed her to retain what oral history theorists call 'composure' was her overriding concern for her children. At every stage, under both the Nazi and the communist regimes, she did what she felt was right and best for her children, growing up as they were without a father. From being a Nazi running the family farm with the use of forced labourers to being a good member of a communist collective farm involved in innumerable good causes (from the GDR perspective) and rewarded with appropriate honours, Ursula B. could register a sense of continuity as a good mother under both regimes (cp. Fulbrook 2013).

Thirdly, analysis of individual subjectivities helps us better understand the significance of a salient past for subsequent generations. Family dynamics under 
different historical circumstances play a major role in shaping the legacies and signification of a particularly difficult past. Gerhard Botz has suggested that in Catholic Austria, tales told in the family played a major role in counteracting official views of the Nazi period (Botz 2005: 15). The same has been claimed for the GDR, but it is not clear that this is quite the case in the same way. Young East Germans experienced pressures to conform and participate in official political institutions and organisations in ways they felt comparable to those experienced by their parents and grandparents under Nazism; this predisposed them to feel some sympathy for the predicaments and possible involvement in or support of Nazism on the part of their parents and to disbelieve the official line of the 'antifascist state', while nevertheless feeling relatively free of any burden of guilt or shame along the lines experienced by their West German counterparts.

More generally, there is much evidence to suggest that the ways in which tales are told about the past reflect not only the wider discourse communities and contexts of telling, but are also shaped by the characters of the interlocutors and the quality of the emotional relationships between the participants in the conversation. This leads us, however, to the heart of the problem: given the ways in which the expression of past subjectivities varies with context, how do we interpret the evidence? How, if at all, can one be sure of the validity of one's own interpretation of the evidence regarding the inner state of a past individual?

\section{The subjectivity of the historian: Personal entanglements}

My reflections on the nature of historical writing go back for many years; but they became particularly acute in my own practice when writing $A$ Small Town near Auscbreitz. This book needs to be introduced briefly.

The city of Będzin was situated some twenty-five miles north of Auschwitz, in the Upper Silesian border region that was incorporated into the expanded Greater German Reich following the invasion of Poland in 1939. My book was at one level a professional history of the role of the civilian administration in the stigmatisation, expropriation, exploitation, ghettoisation and eventual extermination of the 35,000 or so Jews who lived in the town and county of Będzin at the time of the Nazi invasion; only a few survived. The book focuses on one individual, Udo Klausa, the Landrat or Chief Executive of the County of Będzin, who held a role in civilian administration that has been relatively little written about in 'perpetrator research'. The book also recounts the experiences of the Jewish victims, their attempts at survival and resistance in the ghetto, and in trying to blow up the crematoria in Auschwitz in the autumn of 1944.

But at another level this is a highly personal book. My mother was a GermanJewish refugee from Nazi Germany; and my mother's former best school friend, Alexandra, became the wife of Udo Klausa. My book about Klausa's role benefited from access to private family papers; but it was also a 'coming to terms' 
with the previously hidden Nazi past of a man whom I had thought, growing up, that I knew very well. In the process, I challenged and fractured the picture held of Klausa by members of his family as well as by people who knew him after the war as a senior and respected West German civil servant.

In Klausa's memoirs there is no hint of remorse, no explicit acknowledgement of the extent and implications of his own involvement in the racist system that led to genocide. There is only the constant reiteration of his own innocence, his desire not to become 'innocently guilty', and his alleged ignorance of anything that could be construed as 'truly evil'- at least until the major deportation of August 1942, or even until 1944, at which time, so he claims, he first heard about the 'real function' of Auschwitz through a casual encounter on a train. His tales are depressingly familiar, and many Germans must have heard such stories. I felt sceptical, particularly given his political prominence in an area so close to Auschwitz.

When I initially spoke with one of his sons, the stories Klausa had told all seemed reasonable and plausible, and my own views and suspicions began to appear - as this son put it to me - rather 'prosecutorial'. Was I reading too much into any scrap of evidence? On the other hand, once I started investigating the archival sources more closely and compared what I found there with Klausa's memoirs, or his self-defence statements in legal investigations, or in the tales repeated by his son to me, it became increasingly clear that there were startling omissions, misleading statements, and errors in dating, which cumulatively could be seen as amounting to a cover-up job. Or, as his son put it to me, they could be seen as the vicissitudes of memory in old age. One way or another, whether Klausa misremembered wilfully or unintentionally, the version he portrayed of his past was far more benign than the version that historical reconstruction from the sources - including listening to the voices of victims, and realising the horrific effects of Nazi policies which Kluasa put into practice - would suggest was in fact the case. A memoir that barely mentions the Jews for whom Klausa as Landrat was responsible, and which explicitly claims that they had already been ghettoised before his time, when he was in fact himself responsible for their resettlement, 'concentration' and ghettoization, is clearly repressing a quite unpalatable truth.

There are contemporary hints as to Klausa's inner state of mind at the time, all ambiguous and open to a variety of interpretations. Klausa's wife Alexandra, in war-time letters to her mother in Berlin, wrote repeatedly about Klausa's 'nerves'. This could be interpreted in different ways: was it a question of 'nerves' rooted in an inherited nervous predisposition, as his wife at one point suggested; or caused by worry about promotion prospects and chances of being confirmed in post, despite being a Catholic, as she also intimated; or occasioned by continuing illhealth following a war wound and intestinal operation? Or was it a case of acute anxiety about continuing to be involved in what was ever more clearly a murderous enterprise? There is no clear way of deciding on the meaning of Klausa's 'nerves', and providing a definitive interpretation at this distance. Even with the 
relative wealth of evidence available, there is for the historian no easy access to Klausa's inner state at the time - certainly nothing comparable to what a novelist would be able to portray.

There can also be disagreements about Alexandra's comments at the time, particularly when she records in a letter to her mother the deportation of '15,000 Jews' on 12 August 1942, and the bloody ghetto clearance in the summer of 1943. What to my eyes read like comments more concerned with her own wellbeing and safety than with the fates of those being deported can be interpreted by others as evidence of courage, that she even dared write about such matters in a letter during war-time. For Klausa's son, these comments come close to resistance; for me, they represent the heart of the problem of 'bystanders' turning a blind eye; despite seeing, refusing to acknowledge, let alone act on, the criminality of what is going on before their own eyes.

Interpreting the mind-sets of perpetrators or bystanders might risk, on one version of the events, coming dangerously close to exculpation. The question here concerns the extent to which one accepts and reproduces the perpetrators' or bystanders' own accounts at face value; and the extent to which a reconstruction of their own rationale or mentality appears to provide plausibility, even inevitability, to their actions. In fact, much of my book was aimed at precisely querying and analysing the ways in which perpetrators and bystanders later rationalised their conduct, suppressed and reframed some aspects of their past, and were able to live with and present themselves to others in supposedly 'acceptable' ways in the postwar West German context. This is not without its own ethical dilemmas, as when giving greater weight to certain voices than others, and reserving scepticism for the claims of perpetrators rather than survivors. It is hard to critique the latter, even where they too often stray from a strictly accurate record of events. We tend to be more sympathetic to lapses of memory among victims or ways of reframing sensitive stories, which are (not always, but generally) less likely to be rooted in attempted self-exculpation.

Because of my unease about the enterprise of challenging the views of someone I knew personally, despite my loathing of what he stood for, I leant over backwards to give voice to the Klausa family's interpretation, as articulated by the son who had most concerned himself with the issues. I indeed did so to such an extent that some reviewers, who read the book too hastily or misunderstood the nuances of the text, suggested I was if anything too sympathetic to the family's perspective. ${ }^{6}$ But a rather different ethical question was raised for me here. Even if none of the protagonists remain alive, there are almost inevitably rela-

6 For an example of simple textual misunderstanding, see the review by Markus Roth at $<$ http://hsozkult.geschichte.hu-berlin.de/rezensionen/2013-2-184>. Roth mistakenly thinks that when I reproduce the family's version of a particular incident, I also endorse it - although it should be evident throughout the book that I constantly juxtapose family versions with what I think was more likely the actual case, and try to balance the arguments as best I can in light of the evidence. 
tives, even close family members (such as children) who are affected by the exploration of intimacies. What right had I to disturb the privacy of the Landrat's family and challenge their view of a father whom they loved and respected? Should I not have just satisfied my own curiosity, written out my own anger by juxtaposing later accounts with the sources of the time, and then let it rest? And why should I upset a long-standing family friendship? These questions bothered me immensely in the course of writing; for I had to write, in order to understand - not writing the book at all was not an option for me, though not publishing it might have been. Yet would writing without also publishing have amounted to giving posthumous victory to a very widespread form of Nazi cover-up, and silencing, yet again, the voices of the victims?

Moreover, Klausa's case was so very typical, not least in his desire to distinguish himself from the fanatical 'real' Nazis (hence the term 'ordinary Nazis' in the subtitle), who were on his account those really to blame. The role of civilian administration was something that clearly needed to be explored further, having fallen below the public radar of attribution of guilt; and so many were involved in administering a system that made mass murder possible. In telling Klausa's story, might I not be able to assist in broader processes through which many more could understand relatives who had gone along with the Nazis? This rationale made it look even more like a public duty, even despite the private pain caused to members of the immediate family.

There is also a question of privacy. One could say that, had Klausa not brutally disrupted and destroyed the private lives of the Jews of Będzin, I need not have worried about disturbing the peace of his own family, despite the latter's innocence - or at least the innocence of the Klausa children. His wife, living in the villa of a persecuted Jew, could well be seen as one of Hitler's witting beneficiaries. This brings to centre stage again the question of how to write a historical account that remains at the level of 'objective' history.

When we feel deeply about a particular subject, it is not always easy to write to produce the actual text, the narrative on the page - by the implicit rules of historical writing as a scientific discipline. In A Small Town near Auschreitz, I broke several of the classic yet largely unwritten rules of professional history; and I did this knowingly at the time, because I was, frankly, just too choked up about some of what I was writing. I finished the chapter on 'Final Thresholds', largely about Auschwitz, not as I 'should' have done with a reasoned summary and conclusion, but with a quotation from a survivor which I felt I simply had to juxtapose to what seemed to me the quite sickening self-exculpatory tales of the perpetrators who got away with little or no serious consequences; the West German investigators simply took perpetrator tales of absence, ignorance and innocence at face value. I wrote myself into the account not just in the Preface, but many times during the text, including in the concluding chapter where I ruminate not only on the 'person of contemporary history', Udo Klausa, but also on a private 
person, Alexandra, who should have on general historical rules have been anonymised (difficult when married to a man who can be named). I wove many victims' voices into the account not only because the development of their state, their progressive degradation, humiliation, starvation, was so closely intertwined with the Landrat's policies of ghettoisation and reduction of rations that to explore 'perpetrators' and 'victims' separately would have done a complete historical injustice, but also because I wanted, in some sense, to memorialise at least a few of them. And I wanted to demonstrate to the Landrat, albeit posthumously, just what the consequences of his policies - 'only administration', as he called it - actually were for the people on the receiving end of Nazi racism.

All this was not done in purely disinterested spirit. It was not, in Max Weber's terms, 'objective history'. Does this make it bad history? Or is this not also what historians should at least sometimes be doing, if understanding the past really matters in a later present? Let me step back now from the Klausa case and briefly introduce a wider theoretical framework of analysis.

\section{Situated historians and contemporary bistory}

In my current research on legacies of Nazi persecution among victims, perpetrators, and subsequent generations, I distinguish between what I call communities of experience, connection and identification. Each of these is defined by its distinctive relationship with a past that is, for one reason or another, of heightened emotional significance.

Survivors of life-changing, often traumatic periods and events, may form a distinctive 'community of experience'; for all their internal, pre-existing differences and the individual character of their routes through life-threatening challenges, they have shared experiences which, in retrospect, give them common ground, a shared understanding of extraordinary experiences, if not actually similar narratives. Survivors of Nazi persecution form a very different community of experience from those who were on the side of the perpetrators, or from others who were at a distance from these events.

'Communities of connection' consist of those who are intimately connected with a particularly significant period or set of events, even though they did not experience these themselves. Those who are closely connected to both victims and perpetrators are often, in quite different ways, deeply affected by the consequences of life-changing events for others. They may not know much, if anything, by way of details, but they certainly feel the effects through patterns of behaviour, attitudes, and long-term scars, as in the case of children of those Holocaust survivors who do not talk about their past but are deeply affected in their behaviour and functioning. This is not inevitable, however, and may vary with context. Sometimes people only discover quite late in life precisely how they have been affected; the children of perpetrators, for example, may be un- 
aware of their parents' involvement in atrocities or their role in a system of terror until this comes to light through chance discoveries or a legal case or television documentary. But they are nevertheless connected, in a personal and perhaps disturbing way, with this particular past, whether they are aware of details or engage in the work of piecing together a narrative, or whether they prefer to deny, evade, or resist any such engagement.

Finally, 'communities of identification' are those who strongly identify with one or another past group. This may be because they feel that they themselves belong to a particular collective identity with special historical responsibilities as is often found, in very different ways, among Jews with no personal Holocaust background, and among West Germans who have grown up with a public culture of shame. Or it may be because they have been personally moved by a particular story or phenomenon and choose to commit themselves to actions in service of a particular cause or mission - such as memory activists working on behalf of groups to which they do not themselves belong.

These categories are not mutually exclusive, nor are they exhaustive. There are, for example, many historians of Nazi Germany who do not have any personal connections with this period or place; and there are many who identify strongly with the victims, while being descended from perpetrators - a particularly common twist, incidentally. But there are significant and striking numbers of people with strong personal and emotional connections in one way or another, and the significance of this analysis for historical approaches bears closer analysis.

The well-known debate in the 1980s between Martin Broszat and Saul Friedländer is, for example, highly suggestive (cp. Baldwin 1990). Broszat, in referring to Jewish memories and views of their descendants, claims that Jewish memory is "a form of memory which functions to coarsen historical recollection" (106). Friedländer counters: "You oppose the rational discourse of German historiography to the mythical memory of the victims", and goes on to ask "why, in your opinion, would historians belonging to the group of perpetrators be able to distance themselves from their past, whereas those belonging to the group of victims would not?" (110). He has a point - and one that was amply demonstrated by the stance taken, for example, by Andreas Hillgruber in his brief pair of essays in Zweierlei Untergang, where Hilgruber's evident sympathies with German soldiers (including his brother) battling on the eastern front contrasted sharply with the cool, detached tone of his 'scientific' remarks on the Holocaust that continued to rage behind the lines. This was one of the interventions precipitating the renowned Historians' Controversy (Historikerstreit) of the mid-1980s, although Hillgruber's writing style was less at issue in that debate than were questions about the uniqueness of the Holocaust, and rhetorical questions posed by Ernst Nolte about whether Hitler was in some sense an 'answer' to the allegedly 'prior' crimes of the Gulag (cp. Hillgruber 1986). ${ }^{7}$

7 Key texts from Hillgruber (1986), including that of Ernst Nolte, are reprinted in English in Knowlton/Cates (1993). 
Without going further into the substantive issues raised by these debates, which now in many respects appear outdated, there remain unresolved questions around the portrayal of historical subjectivities and the presence of our own subjectivity in our work.

We still need to develop criteria that will allow us to distinguish 'good' and 'bad' historical practice, even when a historian is engaged with the subject matter at a personal level. This may be particularly urgent in the case of histories that are not merely about historical subjectivities, but with which we are also intimately connected.

\section{Engaged history}

Why do people read more fiction than history? In part because fiction seems to be about people, and, ironically, history often does not. Works of fiction generally operate with a relatively small cast of characters, and an intense focus on the relations among just a few, while historical works may be vast in scope and canvas, with the structure and emplotment of the account revolving around a theme that can only be addressed on a broad scale. It may be harder for historians than novelists to deploy personal details and individual stories while maintaining the focus on the analytic questions that lie at the heart of history. Most historians have struggled with the question of balancing structural overviews with in-depth analysis of detailed cases, and maintaining the reader's interest across all parts of the work. There are striking exceptions to this, generally in historical works specifically intended by their authors to be accessible to as wide a public as possible. These works raise particular questions regarding style and balance.

One such book, which gained massive publicity, was that of Daniel Jonah Goldhagen's best-selling Hitler's Willing Executioners: Ordinary Germans and the Holocaust (Goldhagen 1996). This book was subjected to massive critique on grounds of historical inaccuracies as well as illogicality of argument. In my own view, a serious problem with it is that it postulates, and then tends to reify, a particularly virulent form of antisemitism in Germany that was supposedly able to lie 'dormant' for decades in the eighteenth century, reawakening later when the time was ripe. Moreover, Goldhagen generalises from a small group who happened to come from a cross-section of society to all of that society, and similarly lumps 'Germans' together in a rather undifferentiated fashion. And while an alleged mentality is held responsible for massive crimes in the Third Reich, suddenly, with the change of political system in 1945, redemption appears to be at hand and an institutional analysis takes over from the explanation in terms of mentalities that had been harnessed to account for the developments of preceding centuries. Despite these problems, however, Goldhagen's book enjoyed massive appeal - in part because of the vivid and impassioned style in which it is 
written, which evokes atmosphere and place in a way that the arid prose of some of Goldhagen's opponents, notably Hans Mommsen, did not.

It is the character of Goldhagen's writing style that is of interest here. We might want to think that Goldhagen's book represents bad history - for the reasons briefly alluded to above - but nevertheless good historical writing. However, this is disputable. Goldhagen certainly provides us with a sense of immediacy, a vividness of detail, such that readers are able to feel with the victims in a way similar to when reading a novel. Yet is this sense of immediacy actually rooted in the evidence in the way demanded of a historian, rather than a novelist? Goldhagen almost, indeed, employs a form of 'erlebte Rede'. Consider the following passage:

It is difficult to convey the misery of these women as they dragged themselves, often shoeless, along frozen roads, one pain-filled step promising but another, one pain-filled day yielding seemingly inevitably but another. The women had no known destination, no end point in sight. Every step required the marshaling of their energies, for they were at best listless, in their emaciated and diseased conditions. Every dawn saw them awake to gnawing hunger, swollen and pus-filled feet, limbs that no longer functioned, and open wounds that would not heal. (350)

Thus far, this passage is emotive, yet entirely within what can be known and represented by the historian. It then, however, switches into more novelistic mode, conveying the women's thoughts and feelings as they anticipated the course of the coming day and night:

They knew that an entire day's march stood before them, during which they would be given by their tormentors few opportunities to rest. Perhaps, when evening finally came, they would consume a few morsels of food. They would then end the day in shivering, pain-filled half sleep, only to awaken to the repetition of another day's and night's cycle of horrors. (350)

We shift from the historian's perspective - 'it is difficult to convey the misery' to entering the collective minds of the women - 'They knew that an entire day's march stood before them'. Goldhagen effectively takes us inside the heads of the women on the death marches, as they face each new day, and anticipate what lies before them. And this is not founded in any historical evidence provided in the text itself.

Even so, there is an aura of authenticity around this formulation, quite probably rooted not only in the reading of countless documents but also conversations in the home as Goldhagen grew up. We can in a sense see Goldhagen as a member both of a 'community of connection' and of 'identification' - in effect, writing on behalf of his own father, who was a survivor of the Holocaust, as well as on behalf of 'Jews' who are clearly contrasted with 'Germans' in his work - and for whom Hillgruber had written with such clear empathy. In writing in this way, Goldhagen challenged traditional disciplinary boundaries, as articulated in Karyn Ball's attempt to "highlight the behavioral and stylistic codes that determine acceptable approaches to the Holocaust". Ball suggests that scholars 'draw on a 
nexus of models, expectations, and protocols that define a disciplined (i.e., consistently rigorous) approach to an object of inquiry". Furthermore, this "exerts a normative power to determine the parameters of the object of inquiry, to establish the ethics of its representation, and to regulate membership in the discourse community that focuses on it" (Ball 2008: 21). Ball points out that disciplinary practices of objectivity and apparent neutrality may not always be appropriate:

Goldhagen exposes a professional ethos that hardens us against the traumatic excrescences of persecution and mass death. Yet it is worth questioning the assumption that mourning for genocide can be subject to a statute of limitations and the statements of those affected are authoritative only when feelings do not color their perceptions. Goldhagen's impropriety is a symptom of posttraumatic anxiety among members of a vulnerable group, the rage of the betrayed minority clamoring at the gates of a selfentitled majority that aided or turned its back on murder. Traumatic events challenge historians to open these gates by divesting themselves of a scientistic equanimity that is barbaric in the face of genocide. (43-4)

This is in essence the point that Friedländer sought to make in his debate with Broszat - that 'objectivity' is in itself a value position in this context. However much one may disagree with both Goldhagen's explanatory framework and his over-stepping the boundary between historical writing and empathic identification with characters that is typical of fiction, the popular appeal of his work underlines the problems with too cold and detached a writing style.

There are further commitments that a historian must honour (and that a novelist need not, or not in the same way). One is balance in the emplotment of the account. However accessible and readable a book written for a wider public aims to be, and however much it makes use of personal stories to enliven and illuminate the subject matter, the professional historian has a duty to try to engage in adequate research and balance the evidence rather than simply developing and illustrating a one-sided interpretation. ${ }^{8}$

The possibilities inherent in the representation of historical subjectivities are raised strikingly in the writing of Saul Friedländer, who was himself a child survivor, in his two-volume history of the Nazi persecution of the Jews (Friedländer 1997, 2007). Friedländer uses quotations from witnesses, particularly the poignant voices of victims facing imminent disaster and annihilation, not so much to illustrate broader points, evoke atmosphere or arouse sympathy on the part of the reader, but rather as 'ruptures', voices from the past who do not yet have the benefit of hindsight, to disrupt an otherwise over-coherent narrative. In effect, in Friedländer's work we have two separate accounts juxtaposed, laid out side by side. As Alon Confino argues, Friedländer's work essentially combines two approaches, and represents both a form of conventional history writing and an art

8 This is a problem I have relating to Anne Applebaum's highly readable yet selective and slanted recent work (the subtitle summarises the thesis) -The Iron Curtain: The Crushing of Eastern Europe (Applebaum 2012). 
form (Confino 2012: Ch. 3). First, there is a conventional chronological framework, with an interpretative and explanatory structure, emphasising the significance of the ideology of antisemitism and of official policies and orders. But secondly, alongside this there is a fractured, ruptured narrative, with the voices of witnesses intruding, breaking up the narrative. They are not used, as in more conventional historical writing, to illustrate a broader point that the historian is making; rather, they simply speak out from the past, in their own terms, without the benefit of hindsight. Moreover, they appear and disappear, in Confino's view, as characters in a novel might do, in their own right. In this way, Friedländer is able to recognise what Confino calls the 'the strangenesses' and otherness of the past. Even so, Confino uses the example of witnesses expressing their disbelief to make the more general point that this should not be viewed as a rupture, but actually as an integral part of the story itself; that we need to build in a cultural history of the mentalities that were part of the world that made the Holocaust possible.

A more conventional approach to the use of witness sources can be found in the work of a historian such as Richard J. Evans, who uses sources effectively to illustrate wider points he wishes to make, without focusing on the subjectivities as a central part of his argument. ${ }^{9}$ Quotations generally serve to underline the wider points Evans is making; they add an element of flavour, and give an air of credibility to the historian's authoritative voice, suggesting a wider basis on which the argument is built; but they do not themselves form the direct focus of the discussion. There are many other ways in which historians integrate subjective voices into their accounts, from Christopher Browning's use of testimony to find out more about what the past was like - to explore aspects not available in archival sources - to the rather different kind of celebration of testimony in its own right, characterised by respect and even veneration of survivors, and a concern with the authenticity of their anguish rather than the factual veracity of their accounts, as in so much of the literature on Holocaust survivors. Whatever the individual differences across these and many other possible examples, the point here is a broader one.

\section{Conclusion: History as a creative act}

Historical books may themselves be interventions in the debates of the present, which is always informed by interpretations of the past - but there are disciplinary parameters, and it may be time to review these more explicitly. Particularly when writing about a peculiarly significant past, one in which historians are themselves engaged - whether because of personal connections or wider identifications - questions can be raised about the involvement of the historian's own subjectivity, the approach to historical subjectivities, and the eventual style of

9 See for example use of the quotation from Wilm Hosenfeld in Evans (2008: 103-4). 
writing. There are no clear and obvious answers in any of the areas touched on above. Historical writing is in itself a creative act, and an active engagement with a past that we can imagine, but we cannot invent. Overstepping the boundaries between factual and fictional narrative can clearly be problematic; but to stay too safely within the conventional limits of historical writing as a supposedly objective science rather than a creative art can also, in some ways, do an injustice to the significance of the topic and the audiences the historian is seeking to serve.

\section{Literature}

Abrams, Lynn (2010) Oral History Theory. London: Routledge.

Applebaum, Anne (2012) The Iron Curtain: The Crushing of Eastern Europe. New York: Doubleday.

Baldwin, Peter (1990) Ed. Reworking the Past: Hitler, the Holocaust and the Historians' Dispute. Boston: Beacon Press.

Ball, Karyn (2008) „Disciplining Traumatic History: Goldhagen's 'Impropriety'“. Disciplining the Holocaust. NY: SUNY Press. 19-44.

Borscheid, Peter (1986) „Alltagsgeschichte - Modetorheit oder neus Tor zur Vergangenheit?"“. Sozialgeschichte in Deutschland. Vol. I. Eds. W. Schieder and V. Selli. Göttingen: Vandenhoeck \& Ruprecht. 78-100.

Botz, Gerhard (2005) „Einleitung. Jenseits der Täter-Opfer-Dichotomie lebensgeschichtlich erforschen und essayistisch beschreiben“. Schweigen und Reden einer Generation: Erinnerungsgespräche mit Opfern, Tätern und Mitläufern des Nationalsozialismus. Wien: Mandelbaum Verlag. 9-20.

Confino, Alon (2012) „Narrative Form and Historical Sensation“. Foundational Pasts: The Holocaust as Historical Understanding. Cambridge Univ. Press. 49-66.

Evans, Richard J. (2008) The Third Reich at War: 1939-1945. London: Allen Lane.

Friedländer, Saul (1997) Nazi Germany And The Jewes. Vol. 1: The Years of Persecution, 1933-39. London: Weidenfeld and Nicolson.

- (2007) Nazi Germany and The Jewes, Vol. 2: The Years of Extermination, 1939-45. London: Weidenfeld and Nicolson.

Fulbrook, Mary (2002) Historical Theory. London: Routledge.

- (2011) Dissonant Lives: Generations and Violence through the German Dictatorships. Oxford: Oxford Univ. Press.

- (2012) A Small Town near Auschwitz: Ordinary Nazis and the Holocaust. Oxford: Oxford Univ. Press.

- (2013) „East Germans in a Post-Nazi State: Communities of Experience, Connection and Identification". Becoming East German: Socialist Structures and Sensibilities after Hitler. Eds. Mary Fulbrook and Andrew Port. New York: Berghahn Books. 33-55.

Goldhagen, Daniel Jonah (1996) Hitler's Willing Executioners: Ordinary Germans and the Holocaust. New York: Knopf. 
Haffner, Sebastian (2002) Geschichte eines Deutschen: Die Erinnerungen 1914-1933. München: Deutscher Taschenbuch Verlag.

Hillgruber, Andreas (1986) Zweierlei Untergang: Die Zerschlagung des deutschen Reiches und das Ende des europäischen Judentums. Stuttgart: Siedler.

Kaplan, Marion (1998) Between Dignity and Despair: Jerwish Life in Nazi Germany. Oxford: Oxford Univ. Press.

Knowlton, James, and Truett Cates (1993) Transl. Forever in the Shadow of Hitler? Atlantic Highlands, N.J.: Humanities Press.

Kocka, Jürgen (1986a) „Sozialgeschichte zwischen Strukturgeschichte und Erfahrungsgeschichte". Sozialgeschichte in Deutschland. Vol. I. Eds. W. Schieder, and V. Selli. Göttingen: Vandenhoeck \& Ruprecht. 67-89.

- (1986b) Sozialgeschichte: Begriff, Entwicklung, Probleme [1977]. Göttingen: Vandenhoeck \& Ruprecht.

Langer, Lawrence (1991) Holocaust Testimonies: The Ruins of Memory. New Haven: Yale Univ. Press.

Wehler, Hans-Ulrich (1988) „Königsweg zu neuen Ufern oder Irrgarten der Illusionen? Die westdeutsche Alltagsgeschichte: Geschichte ,von innen' und ,von unten“". Aus der Geschichte lernen? München: Beck. 130-51.

White, Hayden (1987) „The Question of Narrative in Contemporary Historical Theory". The Content of the Form: Narrative Discourse and Historical Representation. Baltimore/London: Johns Hopkins Univ. Press. 26-57. 
